\title{
Application of the Code of Ethics and Code of Conduct for State Civil Apparatus at Government Agencies in Indonesia
}

\author{
Yusti Fatmaningdyah ${ }^{1}$, Waluyo ${ }^{2}$ \\ \{ yusti210489@gmail.com ${ }^{1} ;$ drwaluyo16@gmail.com ${ }^{2}$ \} \\ Alumni Faculty of Administrative Sciences, Universitas Indonesia ${ }^{1}$; Commissioner of Indonesia State \\ Civil Apparatus Commission $2014-2019^{2}$
}

\begin{abstract}
One of the eight areas of bureaucratic reform change in the 2015-2019 bureaucratic reform road map is the mental change of the Indonesia state civil apparatus. A large number of civil servants involved in criminal acts show that they don't has performed their duties by basic values, codes of ethics and codes of conduct. This article will map out how many agencies already have the regulation that has been mandated in Government Regulation Number 42 of 2004 and Government Regulation Number 11 the Year 2017. The results of an evaluation conducted by the State Civil Apparatus Commission in 2018 showed that only 71 government agencies from 450 government agencies surveyed had agency regulations regarding basic values, codes of ethics and codes of conduct. So, it becomes a challenge to increase the maturity of the implementation of the Civil Servant Code of ethics and code of conduct in all government agencies.
\end{abstract}

Keywords: civil servants, basic values, codes of conduct, codes of conduct, maturity

\section{Introduction}

The State Civil Apparatus (ASN) is the most important asset owned by the state. They are a human resource that drives the wheels of government organizations in Indonesia [1]. Another important role owned by Civil State Apparatus is as a determinant and policymaker that directs the Indonesian people towards progress and can compete with other countries. It can be concluded that Civil Servants are the driving force of the government system in Indonesia. Entering industry 4.0, which is the era of digitalization, it is important to civil state apparatus to be aware of the implementation of codes of ethics and code of conduct. Strategic human resource (SHRM) is based on the belief that to be effective and able to adapt to changes quickly, agencies need realistic information on the capabilities and talents of their currents staff [2]. This should be an awareness for Civil Servants, how much influence they have on a public agency. The State Civil Apparatus is demanded to be able to carry out its performance well and professionally based on basic values and conformity with the validity of the code of ethics and code of conduct set by Law number 5 of 2014.

One kind of Indonesia state civil apparatus is Civil Servants. Civil servants are valuable components that reflect the public institutions in which they work. As a human, civil servant is also not free from a mistake, especially those related to criminal offenses. Data from Indonesia State Civil Apparatus Commission (KASN) in 2017 describe a rank of cases criminal act. Ten 
highest cases of criminal act who involved civil servant and currently in the prison from rank of ten until eight has decency case, persecution, murder, theft, embezzlement, fraud, and child protection. The most criminal offenses involving civil servants are the first rank of corruption with 1.082 civil servants, followed by drug abuses with 328 civil servants Civil state apparatus code of ethics and Code of Conduct. The data can illustrate that there are still many violations of the code of ethics and code of conduct committed by the state civil apparatus. Violations committed can be paired with the provision of disciplinary penalties, recorded in data table 2 the number of civil servants given disciplinary punishment divided into three categories.

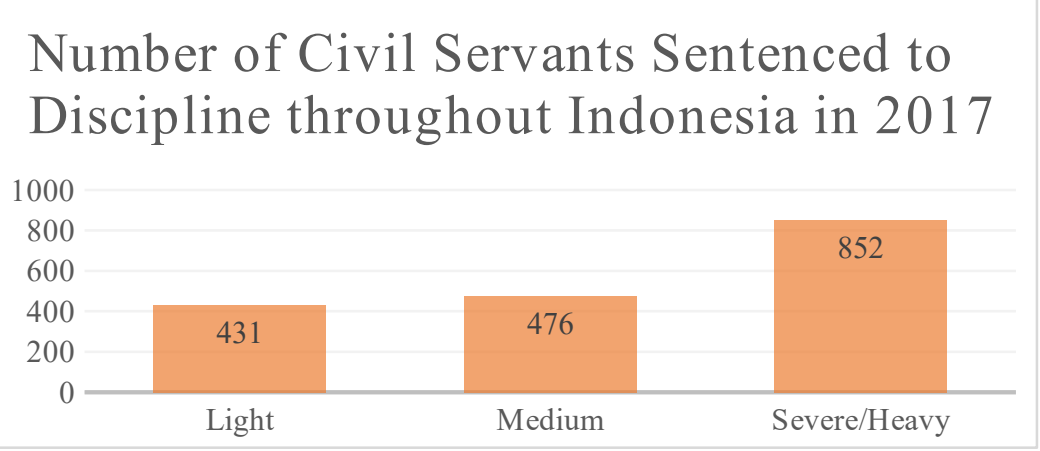

Figure 1. Number of Civil Servants Sentenced to Discipline throughout Indonesia in 2017 Source: BKN Press Release Data 7 Feb 2018, [3]

In 2017 disciplinary punishment for civil servants has been given to 1,759 civil servants. Such violations are based on disciplinary punishment, for example, because the case does not uphold the honor of the state, government and the dignity of civil servants. Besides, some civil servants do not carry out official tasks entrusted and abuse of authority. These violations are inseparable from the lack of obedience to the basic values, codes of ethics and codes of conduct that should be owned by the state civil apparatus.

Mondy, et. all. [4] defines ethics as the discipline dealing with what is good and bad, right and wrong, or with moral duty and obligation. Ethics looks complicated because sometimes it is created to produce short-term benefits, which can potentially conflict with ethical behavior. Daly [5] explains that the policies regarding employee behavior are following specified standards, which are useful for maintaining a sense of civilization in the workplace and professional attitudes. This standard of behavior shows compliance actions with the government which create an honest, open, and professional image, as well as an obedient commitment to public services in the best interests of citizens. Not much different from Mondy's code of ethics according to Daly [5] generally contains rules that are broader in scope than reference codes of behavior, but elements of the code of ethics often appear in government staffing handbooks. The code of ethics and code of conduct should not only be made into rules but must also be made into the organizational culture. This is certainly a good input for government employees and the government as stakeholders if an organization wants to create an ethical culture. Code of ethics and a code of conduct are two different things according to Mondy et. all. [4], code of ethics must have an ethical work culture. Culture pays attention to the way people think, which influences the way they act [4]. Changing organizational culture cannot be done immediately because it requires modification the way thinking of the members organization, namely government officials and also the government. Organizations with a strong ethical culture are believed to be able to take steps to ensure that 
their standards are widely accessible, promoted, and followed by leaders and employees of government organizations.

The enactment of basic value, code of ethics and codes of conduct listed in Law Number 5 Year 2014, article (3), (4) and (5). Specifically, in article 5, the elaboration of the code of ethics and code of conduct is divided into twelve behaviors, namely [6]:

1. The state civil apparatus must carry out their duties honestly, responsibly and with high integrity;

2. State civil apparatus must carry out their duties carefully and indiscipline;

3. The state civil apparatus must serve with respect, courtesy and without pressure;

4. State civil apparatuses must carry out their duties by statutory provisions;

5. The state civil apparatus in carrying out its duties must be following the orders of superiors or officials in charge as long as it does not conflict with the provisions of the legislation and ethics of government;

6. The obligation of the state civil apparatus to maintain confidentiality concerning state policy;

7. Using the assets and property of the state responsibly, effectively and efficiently;

8. Ensuring that conflicts of interest do not occur in carrying out their duties;

9. State civil apparatuses must provide information correctly and not be misleading to other parties who need information related to official interests;

10. Besides, it does not misuse state internal information, duties, status, power and position to obtain or seek benefits or benefits for themselves or others;

11. Upholding the basic values of the state civil apparatus and always maintaining the reputation and integrity of the state civil apparatus;

12. As well as carrying out the provisions of the legislation regarding the discipline of civil servants.

The twelve behaviors above must be obeyed by the state civil apparatus in Indonesia and concerning article 9 of law number 5 of 2014 that state civil servants must be free from the influence and intervention of all groups and also political parties. Mandate of Government Regulation Number 42 Year 2004, Chapter V Article 13 number (1) letter (a) and Government Regulation Number 11 Year 2017 article 101 number (4) states that agencies or organizations that have functional positions (JF) are required to make a compilation to rules of ethics and codes of conduct in the form of ministerial regulations, governor regulations or regulations of the head of the agency. However, the maturity of implementation this regulation is still weak [7].

The function of the code of ethics and code of conduct is to foster character or character, maintain a sense of unity and unity as a family to realize cooperation and the spirit of community service and increase the ability and role model of civil servants [8]. Then encourage the work ethic to realize high-quality employees and aware of their responsibilities as elements of the state apparatus, and public servants. The last function is to foster and increase the spirit, awareness and national insight to maintain the unity and integrity of the nation in the unitary state of the Republic of Indonesia.

This article focuses on the discussion of the application of the code of ethics and code of conduct in every government agency in Indonesia. See how many government agencies have carried out the mandate of Government Regulation Number 42 of 2014, Chapter V Article 13 number (1) letter (a) and Government Regulation Number 11 of 2017 article 101 number (4) [9]. Besides, it also analyzes the maturity of government institutions in implementing basic values, codes of conduct and codes of conduct for civil servants. Prier et al. [2011: 3684] 
argues that the maturity or maturity model of policy implementation is an enabling process of interaction between institutional stakeholders to achieve predetermined objectives of the applied public policy. So, this article will also be able to see the maturity of implementing policies on basic values, codes of conduct and codes of conduct for civil servants.

\section{Research Method}

Discussion on the application of codes of conduct and codes of conduct for civil servants in government agencies in Indonesia using the document study research method (Study literature) with qualitative perspective. The data and articles obtained are then processed, read and examined carefully by the researcher, to form a clear analytical picture. This article uses data survey results of internal regulation-based value, code of ethics, data code of conduct of 2018, data reasons for the ineffectiveness of the code of conduct and code of conduct from State Civil Apparatus Commission (KASN) and discussion with commissioner and staff of State Civil Apparatus Commission 2014-2019.

\section{Analysis}

The code of ethics and code of conduct for employees, especially civil servants, are important matters which are the basis for their daily behavior and services. Civil Servant is a profession that is highly related to the state. It has been explained in introduction that basic values, codes of ethics and codes of conduct are mandatory things that must be possessed by organizations that have functional positions. Almost all public organizations in Indonesia have functional positions, so obligatory every public agency must have regulation codes of ethics and code of conduct.

Some of research identified the code of ethics and code of conduct civil servants only relevant with corruption, even though corruption is only one result from the many consequences that arise not implementing and adhering to basic values, codes of conduct and codes of conduct. Table 1 data in the introduction notes the top ten criminal actions involving civil servants, indeed the most cases are corruption cases, but that does not mean ignoring other cases. The total of Indonesia civil servant data 2018 was 4,185,503 people with 939,236 people assigned to central agencies (22.44\%) and 3,246,267 (77.58\%) assigned to regional agencies [10]. Based on data Indonesia State Civil Apparatus end of January 2018 registered 1.879 civil servant involve criminal act and currently in prison. 


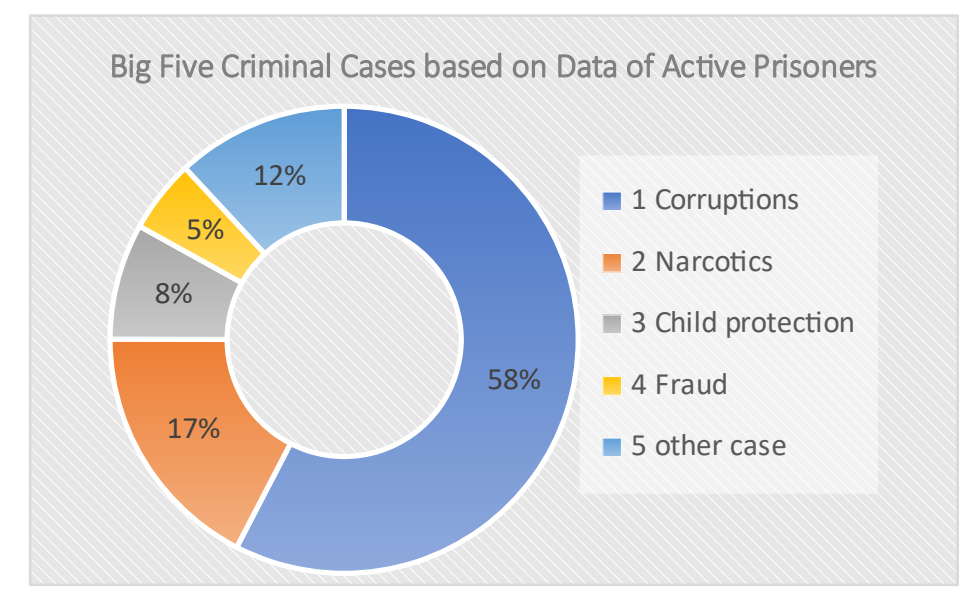

Figure 2. Big Five Criminal Cases Based on Data of Active Prisoners as Civil Servants Source: [11]

Figure 2 from 1.879 civil servant, $58 \%$ on corruption criminal act, $17 \%$ drugs abuse, $8 \%$ Child protection, $5 \%$ fraud and $12 \%$ other case. Even if compared to the total of all civil servants in Indonesia, if the percentage is not more than 1 percent, this should still be a concern of the government. Looking at the data further proves that regulations regarding basic values, codes of ethics and codes of conduct are very important possessed by every public agency in Indonesia. The results of the evaluation of the State Civil Apparatus Commission (KASN) in 2018 recorded only 71 (seventy-one) agencies out of a total of 450 (four hundred and fifty) government agencies that had compiled or had rules of basic values, codes of conduct and codes of conduct. A total of 62 (sixty-two) government agencies out of 71 (seventy-one) have made these regulations since the enactment of the law on the civil service in 2014. This shows that there is still a lack of awareness of government agencies, both central and regional, in mandating the laws and regulations relating to basic values, codes of conduct and codes of conduct in their institutions. Even though the agency regulations that have been made are more dominant about employee discipline, 71 institutions have been able to fulfill the mandate of the laws and regulations.

A review from the 2018 state civil service commission also said these the agencies had conducted socialization on their organizations. Unfortunately, Internal Socialization is only one-way, so it is believed that it has not been well socialized within the organization. This agency regulation has not yet been socialized because it is only carried out in certain regional work units, such as the regional secretary, inspectorate, and regional personnel agency (BKD). Seventy-one agencies, unfortunately, do not all have a code of ethics assembly, only $7 \%$ about five agencies that have them. Whereas it is important to have a code of ethics assembly, which has the function of regulating, supervising and providing sanctions for civil servants who violate the rules of code of ethics and code of conduct. Some recorded cases such as neutrality, discipline, divorce, infidelity, etc., must all be resolved by ethics council at their respective institutions.

Imposing sanction in violation of the code of ethics and code of conduct sometimes cannot run smoothly. In the process of resolution, ethical dilemmas often occur. Ethical dilemma is a situation face by someone who must make decisions about what kind of behavior 
is right for him to do. The process begins by considering in two ways, the first is that there is no reason to engage in unethical behavior/conflicts of interest and the second is that actions are considered unethical if they do not pass a series of test. Ethical testing is carried out by considering aspects of legality, pride in deeds, self-comfort for deeds, stakeholder opinions, shareholders see it as a service responsibility and how the reputation of the agency. As for ethical behavior and conflict of interests related to the principle of basic value, code of ethics and code of conduct as well as commitment and moral integrity in the public service. Both considerations must be consulted with the ethics council.

When discussing conflicting interests, this can occur if individuals or organizations are involved in various interests. According to Macdonald, et al. [12] conflict of interest is a situation where someone has a personal interest that affects the objectivity and goals of the organization. Three key elements underlie the conflict of interest, namely, first, the existence of personal interests, financial or personal benefits. Both of these personal interests' conflict with official duties performed, and the three conflicts of interest interfere with professional responsibility in a certain way, namely by interfering with objective professional judgment.

Conflicts of interest greatly affect the performance of civil servants, even though a civil servant must be neutral in carrying out his duties. The neutrality of civil servants listed in Act Number 5 of 2014 concerning State Civil Apparatus, article 2 letter (f). The principle of neutrality is to not take sides from any forms of influence and not to side with any interests, be objective in carrying out their duties, be fair when carrying out their duties, free from any outside party intervention, and free from conflicts of interest. The implementation of neutrality according to Hazell, et al [13] is divided into four dimensions: the first is neutrality when conducting elections (political element), the administration of public services, decision making/policy, and management of the state civil apparatus.

The main factor that causes many violations of the code of ethics and code of conduct of civil servants is the lack of effort to enforce the code of conduct and code of conduct within the environment of government agencies. The reason is that there are still many local governments that do not yet have an internal regulation regarding the code of ethics and codes of conduct within their organization. In figure 2, out of 450 government agencies surveyed by the state civil service commission, only $3.8 \%$ of ministries, $50 \%$ of provinces and $16 \%$ of regencies/cities have agency internal regulations on basic values, codes of conduct and codes of conduct.

Figure 3. Survey Results of Internal Regulation Base Value, Code of Ethics and Code of

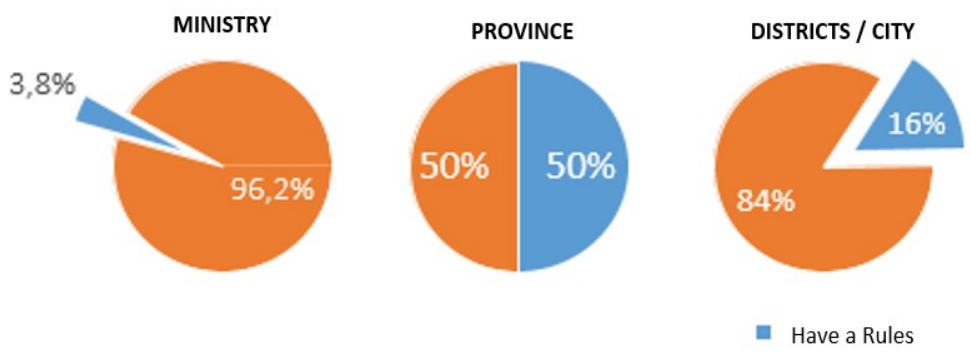

Conduct of 2018

Source: [14] 
The ineffectiveness of socialization carried out by agencies is also the reason why there are still many violations of codes of conduct and codes of conduct. Intense employees do not understand the rules regarding basic values, codes of conduct and codes of conduct. If you look at Figure 3, there are 3 explanations of why the lack of understanding of civil servants regarding the regulation, namely not yet done socialization, socialization has been done, internalization has been done.

Figure 4. Reasons for the ineffectiveness of the Code of Conduct and Code of Conduct

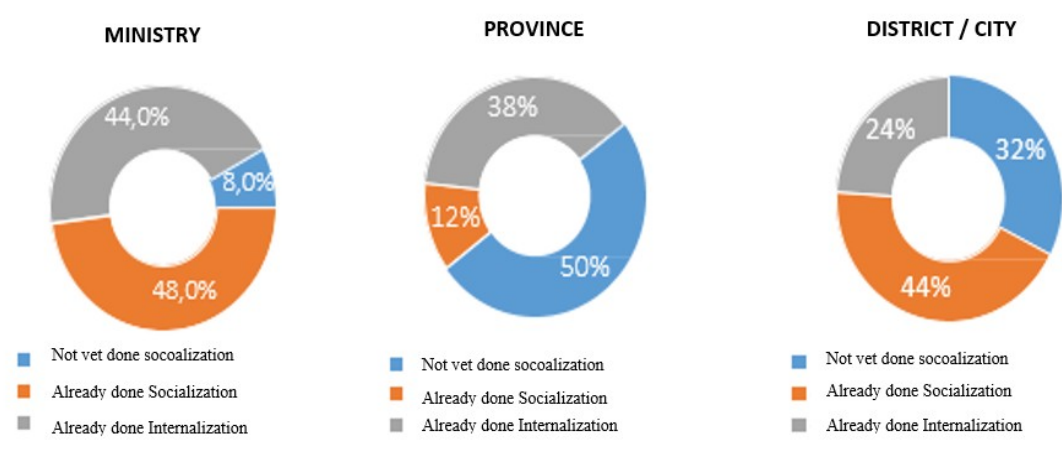

Source: [14]

Figure 4 explains that within the ministry's scope it was noted that $44 \%$ stated that socialization had been carried out internally, $48 \%$ said socialization had been carried out and $8 \%$ said socialization had not been carried out. While for provincial-level agencies stated $38 \%$ had been carried out internally, $12 \%$ had been socialized and $50 \%$ stated that socialization had not yet been carried out. The Regency / City level also stated that $24 \%$ had conducted internal socialization, $44 \%$ said they had conducted socialization and $32 \%$ said that they had not yet been socialized. The lack of socialization of the basic value regulations, code of ethics and code of conduct, especially in the scope of the province, confirms the cause of the increasing number of violations of codes of conduct and codes of conduct for civil servants in Indonesia.

If you look at the previous description it can be seen that all are interrelated between adherence to basic values, codes of conduct and codes of conduct with conflicts or conflicts of interest that tend to be more for personal interests which ultimately leads to the absence of neutrality of civil servants which leads to corruption and other criminal actions. However, regulations regarding basic values, codes of ethics and codes of conduct that already exist must also be followed and adhered to properly, not useful if a regulation has been made and has been applied, but the awareness to comply or even the awareness to implement it is still lacking.

It was explained earlier that the main factors causing many violations of the code of ethics and code of conduct are the absence of internal regulations that apply to ministries, institutions or local governments and also the lack of socialization of codes of conduct and codes of conduct. Another factor that can be used as a cause is the lack of commitment and role-models from leaders in implementing and complying with the code of ethics and code of conduct. Leaders as role-models cannot yet provide examples of the application of codes of conduct and codes of conduct for their subordinates. The indecisiveness of civil servants in imposing disciplinary action shows the weak commitment of civil servants in implementing the code of ethics and codes of conduct for civil servants. 
The absence of a whistle-blowing system and the effective prevention of ethical violations can also be the cause of a large number of violations that occur. The lack of clarity is related to the protection of a whistle-blower so that it causes the reluctance of other employees to report violations of codes of conduct and codes of conduct. Another contributing factor is the difficulty of obtaining information about the track record of ethical violations from civil servants. This is since the information system regarding employees who have stumbled on legal cases has not yet been developed, making it difficult for the staff development officer to know the employee's track record and this makes the decision taken less precise. These decisions include allowing permitted employees to be transferred to other agencies or promoting problem employees to higher positions.

Another thing that can be used as a basis for thinking about the reasons for the many violations of the code of ethics and code of conduct of civil servants is legal sanctions that are light and do not cause a deterrent effect, because in Government Regulation No. 42/2004 explains that the punishment given is only a moral sanction that has not can be described. The confusion that was seen in the punishment for violating the ethics of civil servants between Government Regulation Number 53 of 2010 concerning Discipline of Civil Servants and Government Regulation Number 42 of 2004 concerning the Soul Corps of Civil Servants. Low public awareness to report violations of codes of ethics and codes of conduct committed by civil servants because of the apathy that has been formed and the community's stigma that civil servants cannot be touched by the law makes it more convenient for civil servants to commit violations that violate codes of ethics and codes of conduct.

\section{Conclusion}

The conclusion that can be drawn from the previous explanation is that the application of the code of ethics and code of conduct in the environment of civil servants in Indonesia has not yet shown maturity. This is because there are still many government agencies that do not yet have basic values, codes of ethics and codes of conduct internally. Although there are already agencies that have, the application is not yet fully implemented, because of the lack of value of the socialization carried out. The leadership component also plays a major role in the application of the code of ethics and code of conduct, where the consistency of the leadership becomes a role model for employees below. Sanctions for violations of the code of ethics are still limited to moral sanctions which are difficult to measure, so it is necessary to review the types of sanctions that can be given.

We still have a lot of home work to make all of the code of ethics and code of conduct effective in every institution special for Government Institutional. All Government institutions should work together to make code of ethics and code of conduct running well. KASN or State Civil Apparatus Commission must be facilitated and supervision as per their authority. We are all as a community should not hesitate if we find violations by Civil Servant.

\section{Refferences}

[1] M. Thoha, Manajemen Kepegawaian Sipil Di Indonesia, Jakarta, DKI Jakarta: 
Prenadamedia Group, 2016.

[2] J. Pynes, Human Resources Management fro Public and Non Profit Organization, San Francisco: Jossey-Bass, 2009.

[3] Republik Indonesia, Badan Kepegawaian Negara, „BKN Press Release 2018,“ Badan Kepegawaian Negara Republik Indonesia, 7 February 2018. [Online]. Available: https:// www.bkn.go.id/wp-content/uploads/2018/02/7-Februari-2017-SIARAN-PERS-HD-PNS2017-1.pdf.

[4] R. W. Mondy a J. J. Marthoccio, Human Resource Management - Global Edition, Pearson Education, 2016.

[5] J. Daly, Human Resource Management in Public Sector : Policies and Practice, New York: Routledge, 2015, p. 168.

[6] Republik Indonesia, Law Number 5, Jakarta, 2014.

[7] Republik Indonesia, Government Regulation Number 42, Jakarta, 2004.

[8] J. Ivancevich, J. Konopaske a M. T. Matteson, Organizational Behaviour and Management, New York: Mc. Graw-Hill Irwin, 2013.

[9] Republik Indonesia, Government Regulation Number 53, Jakarta, 2010.

[10] Biro Hubungan Masyarakat, Badan Kepegawaian Negara, „BKN Press Release No. 058/ RILIS/BKN/IV/2019 Hingga 4 Februari 2019, BKN Telah Tetapkan sebanyak, “ 4 February 2019.

[11] S. C. A. C. „KASN Code of Ethics and Code of Conduct Study, System Study and Development Working Group, State Civil Apparatus Commission,“ Komisi Aparatur Sipil Negara, Jakarta, 2019.

[12] C. McDonald, M. McDonald a W. Norman, „Charitable Conflict of Interest,“ Journal of Business Ethics, zv. 39, \%1. vyd.1-2, pp. 67-74, August 2002.

[13] R. Hazzel, B. Worthy a M. Glover, Impartiality : The Impact of The Freedom of information Central Government in The UK - Does for Work?, London: Palgrave Mc.Milan, 2010.

[14] The State Civil Apparatus Commission;, „Report of The Working Group on Evaluation and Monitoring and Evaluation, The State Civil Apparatus Commission,“ The State Civil Apparatus Commission, Jakarta, 2019. 